\section{References}

1 Allan R, Dykes P. A study of the factors influencing mortality rates from gastrointestina haemorrhage. Qf Med 1976;45:533-50.

2 Himal H, Watson W, Jones C, Miller L, Maclean L. The management of upper gastrointestina hemorrhage: a multiparametric computer analysis. Ann Surg 1974;179:489-93.

3 Crook J, Gray L Jr, Nance F, Cohn J. Upper gastrointestinal bleeding. Ann Surg 1972;175:771-9. 4 Macleod J, Mills P. Factors identifying the probability of further haemorrhage after acute upper gastrointestinal haemorrhage. Br f Surg 1982;69:256-8.

5 Johnston S, Jones P, Kyle J, Neddham C. Epidemiology and course of gastrointestinal haemorrhage in north-east Scotland. BrMed f 1973;iii:655-60.

6 Hunt PS, Francis JK, Hansky J, et al. Reduction in mortality from upper gastrointestinal haemorrhage Med J Aust 1983;ii:552-5.

7 Vellacott K, Dronfield M, Atkinson M, Langman M. Comparison of surgical and medical management of bleeding peptic ulcers. Br Med f 1982;284:548-50.

8 Cox H, Poller L, Thomson J. Gastric fibrinolysis. A possible aetiological link with peptic ulcer. Lancet 1967; i:1300-2.

$9 \mathrm{Cox} \mathrm{H}$, Poller $\mathrm{L}$, Thomson J. Evidence for the release of gastric fibrinolytic activity into periphera blood. Gut 1969;10:404-7.

10 Thomson J. Fibrinolysis and the stomach. Biochemical identification of the "plasmin like" enzyme. Thrombosis et Diathesis Haemorrhagica 1974;31:291-8.

11 O'Brien T, Hadley H, Irving M. Fibrinolytic activity in gastric venous blood. Gastroenterolog 1979;76:509-14

12 Eras P, Harpel P, Winaver S. Histological localisation of plasminogen activator and proteolytic activity in the human stomach and duodenum. Gut 1970;11:851-4.

13 Kondo M, Ikezaki M, Imanishi H, Nishigaki I, Nakai T, Hosokawa K. Role of tissue fibrinolytic activity in gastroduodenal ulcer. Foumal of the Kyoto Prefectural University of Medicine 1975;84: $1021-7$.

14 Callender S, Warner G, Cope E. Treatment of menorrhagia with tranexamic acid. A double-blind trial. BrMed f 1970;iv:214-6.

15 Vermylen J, Verhaegen-Declercq M, Verstraete M, Fierens F. A double-blind study of the effect of tranexamic acid in essential menorrhagia. Thrombosis et Diathesis Haemorrhagica 1968;20: 583-7.

16 Hedlund PO. Antifibrinolytic therapy with Cyklokapron in connection with prostatectomy. A double-blind study. Scand $\mathcal{F}$ Urol Nephrol 1969;3:177-82.

17 Cormack F, Chakrabarti RR, Jouhar AJ, Fearnley GR. Tranexamic acid in upper gastrointestina haemorrhage. Lancet 1973;i:1207-8.

18 Biggs J, Hugh T, Dodds A. Tranexamic acid and upper gastrointestinal haemorrhage-a doubleblind trial. Gut 1976;17:729-34.
19 Engqvist A, Boström O, Feilitzen F, et al. Tranexamic acid in massive haemorrhage from the upper gastrointestinal tract: a double-blind study. Scand $\mathcal{F}$ Gastroenterol 1979;14:839-44.

20 Bergqvist $D$, Dahlgren $S$, Hessman $Y$. Local inhibition of the fibrinolytic system in patients with massive upper gastrointestinal haemorrhage. Ups $\mathcal{f}$ Med Sci 1980;85:173-8.

21 Barer $\mathrm{D}$, Ogilvie A, Henry $\mathrm{O}$, et al. Cimetidine and tranexamic acid in the treatment of acute $\stackrel{D}{D}$ upper-gastrointestinal-tract bleeding. $N$ Engl f Med 1983;308:1571-5.

22 Cochran W. Some methods for strengthening the common $\chi^{2}$ tests. Biometrics 1954;10:417-51.

23 Armitage P. Statistical methods in medical research. Oxford and Edinburgh: Blackwell Scientific, $\Omega$ 1971:363-5.

24 Broberg A, Ihre T, Pyk E. Exulceratio simplex as a conceivable cause of massive gastric hemorrhage. Surg Gynecol Obstet 1982;154:186-8.

25 De Dombal FT, Clarke JR, Clamp S, Malizia G, Kotwal MR, Morgan AG. Prognostic factors in \&

26 Foster DN, Miloszewski KJA, Losowsky MS. Stigmata of recent haemorrhage in diagnosis and

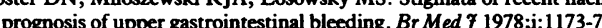

prognosis of upper gastrointestinal bleeding. Br Med $f$ G $1978 ; 1: 1173-7$.
Griffiths W, Neumann D, Welsh J. The visible vessel as an indicator of uncontrolled or recurrent gastrointestinal hemorrhage. N Engl f Med 1979;300:1411-3.

28 Brearley S, Morris DL, Hawker PC, Dykes PW, Keighley MRB. Prediction of mortality at endoscopy in bleeding peptic ulcer disease. Endoscopy 1985;17:173-4.

29 Andersson L, Nilsson IM, Colleen S, Granstrand B, Melander B. Role of urokinase and tissue activator in sustaining bleeding and the management thereof with EACA and AMCA. Ann NY $\overline{\bar{\Phi}}$ Acad Sci 1968;146:642-58.

30 Green F Jr, Kaplan M, Curtis L, Levine P. Effect of acid and pepsin on blood coagulation and $\stackrel{\mathbb{Q}}{\varrho}$ platelet aggregation. A possible contributor to prolonged gastroduodenal mucosal hemorrhage. in Gastroenterology 1978;74:38-43.

31 Berstad A. Management of acute upper gastrointestinal bleeding. Scand $\mathcal{J}$ Gastroenterol 1982;17(suppl 75):103-8.

32 Buhr H, Encke A, Seufert R. Untersuchungen zur lokalen Fibrinolyse des Magens. Chirurg 1978; 二 49.431-5.

33 Kittang E, Aadland E, Oyen D, et al. Effect of peroral treatment of patients with acute upper gastrointestinal haemorrhage: a randomized controlled trial. Scand $\mathcal{F}$ Gastroenterol 1982; 17(suppl 75): 109-12.

34 Hastings $P$, Skillman J, Bushnell $L$, Silen W. Antacid titration in prevention of acute gastrointestinal bleeding. A controlled, randomized trial in 100 critically ill patients. $N$ Engl $f(0$ Med 1978;298:1041-5.

35 McAlhany J Jr, Colmic L, Czaja A, at al. Antacid control of complications from acute gastroduodenal disease after burns. F Trauma 1976;16:645-8.

(Accepted 7 October 1986)

\title{
Reproduction of epigastric pain of duodenal ulceration by adenosine
}

\author{
ANDREW H WATT, DAVID J M LEWIS, JOHN J HORNE, PAUL M SMITH
}

\begin{abstract}
Intravenous boluses of adenosine produced transient epigastric discomfort indistinguishable from spontaneous pain in five of six patients with endoscopically confirmed duodenal ulcer, an effect which was slightly but significantly antagonised by aminophylline.

These findings may be relevant to the pathophysiology of peptic ulcer pain.
\end{abstract}

\section{Introduction}

Adenosine is an endogenous nucleoside, much of which is formed as a metabolite of the nucleotide adenosine triphosphate (ATP). Adenosine exerts various pharmacological effects, including vasoDepartment of Pharmacology and Therapeutics, University of Wales College
of Medicine, Cardiff CF4 4XN

ANDREW H WATT, BMEDBIOL, MRCP, clinical research officer

Department of Medicine, Bridgend General Hospital, Bridgend, Mid Glamorgan

\section{DAVID J M LEWIS, MB, BCH, medical registrar}

Department of Medicine, Llandough Hospital, Llandough, South Glamorgan JOHN J HORNE, MB, MRCP, medical registrar

PAUL M SMITH, MD, FRCP, consultant physician

Correspondence to: $\mathrm{Dr}$ Watt dilatation and cardiac electrophysiological effects. ${ }^{1}$ While investigating the respiratory stimulant effect of adenosine ${ }^{2}$ one subject $(a-$ colleague who had not disclosed that he had a duodenal ulcer) reported that intravenous boluses of adenosine produced epigastric pain that did not differ from his spontaneous ulcer pain, except that it was transient.

Little attention had been paid to the capacity of adenosine to 8 produce or modulate pain with the exception of a study of pain 3 induced by adenosine on a human blister base preparation. ${ }^{3}$ Thus 0 the study aimed at determining whether the adenosine induced ${ }_{N}$ epigastric pain observed in our subject occurred in other subjects with symptomatic duodenal ulcer, whether the pain was related to 0 the dose given, and whether any pain that occurred was modified by aminophylline, a competitive antagonist at cell surface adenosine $\tilde{O}$ receptors.

\section{Patients and methods}

Informed, written consent was obtained from six patients (four men) aged $T$ 25-62 with endoscopically proved duodenal ulcers that had been symptomatic in the week before the study. Two patients with recurrent duodenal $\stackrel{\mathbb{D}}{\circ}$ ulceration had been treated with cimetidine in the past. No patient was $\mathbb{D}$ taking $\mathrm{H}_{2}$ antagonists at the time of study, and no patient had taken oral $\frac{\varrho}{\sigma}$ antacids on the study day. It was made clear to each patient that the purpose of the study was to determine whether adenosine could mimic their $\varnothing$ spontaneous ulcer pain, that any pain was expected to last only a few seconds after any one bolus injection, and that after any injection the study would be stopped at their request. The study protocol was approved by the hospital $\rightleftharpoons$ ethics committee. 
Adenosine and saline were administered single blind as successive rapidly injected bolus doses separated by at least 90 seconds. No saline flush was given after each test injection, but appropriate allowance was made for the dead space of the intravenous cannula $(0.12 \mathrm{ml})$. The initial dose of adenosine was $20 \mu \mathrm{g} / \mathrm{kg}$, increasing in steps of $20 \mu \mathrm{g} / \mathrm{kg}$ to a possible maximum of $200 \mu \mathrm{g} / \mathrm{kg}$; the effects of this regimen on respiration and heart rate have been reported previously. ${ }^{2} 4$ During the stepwise increase in bolus doses of adenosine saline (in a volume equivalent to an adenosine dose of 200 $\mu \mathrm{g} / \mathrm{kg}$ ) and lower adenosine doses were given to minimise any effect of anticipation by the patient on the pain score. The electrocardiogram was monitored throughout the study because of transient dose related bradycardia with this regimen.

After the first adenosine series, which was stopped when a dose of $200 \mu \mathrm{g} /$ $\mathrm{kg}$ was reached or earlier at the patient's request, aminophylline $250 \mathrm{mg}$ was infused intravenously over 10 minutes. A further series of single blind injections of saline and adenosine (starting at a dose of $20 \mu \mathrm{g} / \mathrm{kg}$ ) was then given.

Pain was scored using a $10 \mathrm{~cm}$ visual analogue scale, the left end being labelled "no pain" and the right end labelled "pain as bad as I can imagine." After each injection the patients were asked to score the peak epigastric sensations and, for the purposes of the visual analogue score, to ignore any other symptoms that adenosine might produce. Other symptoms were noted separately. After each injection patients were asked if they wanted to proceed to another bolus injection, which they understood might be at a higher dose.

Pain scores were measured by an observer who was blind to the solution administered. A pain score in mm (scale 0-100) was determined.

The relation between dose of adenosine and pain score over the dose range 60-200 $\mu \mathrm{g} / \mathrm{kg}$ (lower adenosine doses having produced no pain) was examined for the periods before and after aminophylline was given by analysis of covariance. Threshold doses for epigastric sensations and subjective respiratory stimulation were compared using the two tailed Student's paired $t$ test.

\section{Results}

Adenosine produced epigastric discomfort in five of the six patients studied (figure). Before aminophylline was given, epigastric discomfort induced by adenosine was significantly related to the dose given for all six subjects for the dose range $60-200 \mu \mathrm{g} / \mathrm{kg}(\mathrm{r}=0.730, \mathrm{p}<0.001)$. After aminophylline was given pain scores for the dose range $60-200 \mu \mathrm{g} / \mathrm{kg}$ were again significantly related to the dose given $(r=0.790, p<0.001)$ but the intercept was shifted significantly to the right $(F=6.516, p<0.05)$ without a change in slope of the relation $(F=2 \cdot 240, p>0 \cdot 20)$. Adenosine produced no epigastric sensations below doses of $60 \mu \mathrm{g} / \mathrm{kg}$ during the periods before and after aminophylline was given. Saline injections caused little or no discomfort, the mean pain score being 0.5 (SD 1.5) for all saline injections. Pain scores for the group of six after adenosine was given were $13.8(9.0)$ at a dose of $100 \mu \mathrm{g} / \mathrm{kg}$ and $68 \cdot 2(40 \cdot 2)$ at a dose of $200 \mu \mathrm{g} / \mathrm{kg}$.

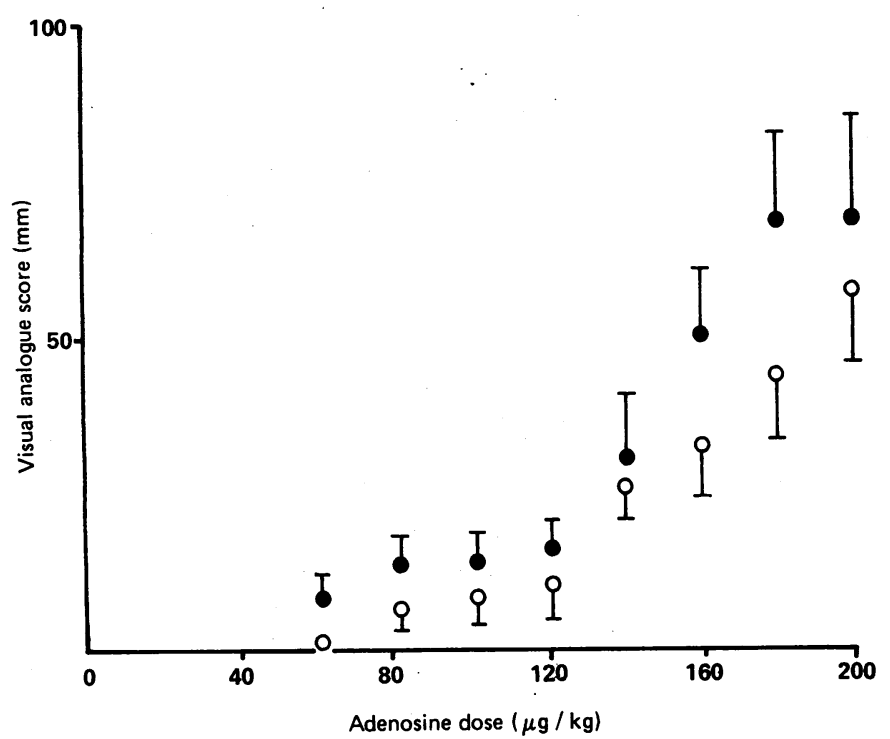

Pain scores after adenosine injections. $=$ Before aminophylline. $O=$ After aminophylline.
Each of the five subjects who experienced transient epigastric pain after adenosine injections was unable to distinguish the peak effect of adenosine at higher doses from spontaneous ulcer related pain. Discomfort induced by adenosine differed from spontaneous pain, however, in that adenosine it was transient, lasting 10-15 seconds.

Respiratory stimulation was reported by all six subjects. In the subjects who experienced epigastric pain the threshold dose for respiratory stimulation $(48(11) \mu \mathrm{g} / \mathrm{kg})$ was significantly $(\mathrm{p}<0.01)$ lower than the threshold dose $(85$ (10) $\mu \mathrm{g} / \mathrm{kg}$ ) producing even the mildest epigastric sensations. In none of the subjects did bradycardia induced by adenosine cause the study to be stopped. Other subjective sensations reported after adenosine injections were facial flushing and neck discomfort. No subject reported retrosternal discomfort. No subjective sensations were reported after saline injections other than occasional minor epigastric discomfort scored on the visual analogue scales.

\section{Discussion}

This study shows that in patients with endoscopically proved symptomatic duodenal ulcer intravenous adenosine boluses above a dose of $40 \mu \mathrm{g} / \mathrm{kg}$ produce dose related epigastric discomfort, which patients were unable to distinguish from spontaneous ulcer related pain other than by the transient nature of discomfort induced by adenosine. This dose related discomfort was slightly but significantly antagonised by pretreatment with aminophylline, a competitive antagonist at cell surface adenosine receptors. ${ }^{56}$

The mechanisms of spontaneous pain related to peptic ulceration are not clear. The two possible mechanisms that have received most attention are smooth muscle spasm and low intraluminal $\mathrm{pH}$, which is now more widely accepted. The theory that smooth muscle spasm may cause ulcer related pain ${ }^{7}$ was not supported by the findings of Bonney and Pickering, ${ }^{8}$ who performed studies showing a poor correlation between pain and increases in intraluminal pressure. Spontaneous ulcer pain in patients with active ulcers is commonly associated with low intragastric $\mathrm{pH}$, and as pain is frequently alleviated by alkali and precipitated by intragastric $\operatorname{acid}^{8} 9$ the concept of acid as a cause of ulcer pain has become widely accepted. When acid is administered by nasogastric tube into the stomach of patients with ulcers there is a delay for both gastric and duodenal ulcers before pain results, possibly due to either hydrogen ion $\left(\mathrm{H}^{+}\right)$ diffusion or production of an intermediate metabolite in sufficient concentrations to stimulate sensory nerves. ${ }^{10}$ The identity of such a metabolite, if it exists, is unknown.

The release of adenosine has been associated with high acid production in the gastric mucosa." Secretion of gastric acid stimulated by histamine and methacholine ${ }^{12}$ is inhibited by adenosine, thus providing a possible adenosine mediated feedback control loop for the control of acid production.

Adenosine can produce pain on a human blister base preparation. ${ }^{3}$ Many effects of adenine nucleotides depend on prior conversion to adenosine, ${ }^{13}{ }^{14}$ and so the capacity of these nucleotides to produce pain may also at least in part depend on the conversion of the adenine nucleotides to adenosine. ${ }^{15}$

The mechanism of the transient epigastric discomfort produced by adenosine in this study is not clear. One possibility is that adenosine causes transient smooth muscle spasm in foregut structures, but this seems unlikely as adenosine has been reported to relax intestinal smooth muscle. ${ }^{16}$ Alternatively, adenosine may increase production of acid by a vagally mediated mechanism, as has been reported at very high doses in the rat. ${ }^{17}$ Even if stimulation of secretion of gastric acid did occur in our patients, however, the occurrence of pain perhaps 20 seconds after the bolus injection of adenosine and lasting about 15 seconds is unlikely to be explained by a fall in intragastric $\mathrm{pH}$ as local instillation of acid takes several minutes to initiate pain. ${ }^{10} 18$

Another possibility is that adenosine concentrations in the tissues near the ulcer are raised before adenosine is given, possibly because of access of acid to the tissue secondary to mucosal damage. When exogenous adenosine carried in the bloodstream reaches this abnormal tissue the sum of endogenous and exogenous local concentrations of adenosine might be raised sufficiently to stimulate sensory nerves and so generate pain. To our knowledge the capacity 
of adenosine to stimulate afferent nerves in the foregut has not been defined, but in cutaneous nerves adenosine stimulates sensory neural discharges with a threshold concentration of 1-3 mM. ${ }^{3}$ Our suggestion that adenosine stimulates sensory nerve endings in the tissues near the duodenal ulcer seems plausible but has yet to be confirmed experimentally.

If adenosine does directly stimulate afferent nerves in tissues other than the skin the possible role of adenosine in the pathophysiology of pain in other conditions where concentrations of adenosine in the tissues are increased-for example, ischaemiawould merit further investigation. Moreover, Sylven et al have recently reported transient angina-like sensations in apparently healthy volunteers and have proposed that adenosine stimulates sensory nerves in the heart. ${ }^{19}$ It is unlikely that these sensations are caused by myocardial ischaemia as we found adenosine boluses to double coronary blood flow while causing similar retrosternal sensations in nine of 10 patients with chest pain but normal coronary arteries. ${ }^{20}$ It is uncertain from which anatomical site such retrosternal sensations arise. The neck, arm, or epigastric sensations that are sometimes associated with retrosternal sensation ${ }^{2}{ }^{19}$ also occurred during intra-aortic infusion of adenosine ${ }^{21}$ into the aortic arch or descending thoracic aorta, which, in view of the fact that the half life of adenosine in human blood is less than 10 seconds, ${ }^{22}$ suggests that sensations in those areas can arise from non-cardiac structures. Interestingly, the only patient in which the intra-aortic infusion study could not be completed was one with a hiatus hernia, who suffered epigastric pain. This may suggest that duodenal ulceration is not the only gastrointestinal inflammatory condition with a predisposition to epigastric discomfort induced by adenosine, and so the association between adenosine and pain may be of greater importance. If our hypothesis that adenosine, in sufficiently high concentrations, directly stimulates pain receptors is subsequently proved a suitable selective antagonist at such adenosine receptors may provide a new method of pain relief in appropriate painful conditions.

\section{References}

1 Anonymous. Adenosine revisited [Editorial]. Lancet 1985;ii:927-8. Anonymous. Adenosine revisited [Editorial]. Lancet 1985;ii:927-8.
Watt AH, Routledge PA. Adenosine stimulates respiration in man. Br f Clin Pharmas
1985;20:503-6.

3 Bleehen T, Keele CA. Observations on the algogenic actions of adenosine on the human blister base preparation. Pain 1977;3:367-77.

4 Watt AH, Routledge PA. Transient bradycardia and subsequent sinus tachycardia produced $\overparen{(6)}$ intravenous adenosine in healthy adult subjects. Br f Clin Pharmacol 1986;21:533-6. intravenous adenosine in healthy adult subjects. Br $\mathcal{G}$ Clin Pharmacol 1986;21:533-6.
5 Londos C, Wolff J. Two distinct adenosine-sensitive sites on adenylate cyclase. Proc Natl Acad
USA 1977;74:5482-6.

6 Londos C, Cooper DMF, Wolff J. Subclasses of external adenosine receptors. Proc Natl Acad \& USA 1980;77:2551-4.

7 Hertz AF. The sensibility of the alimentary canal. Lancet 1911;i:1187-93. duodenum. Part I. The nature of the stimulus. Clin Sci 1946;6:63-89.

9 Palmer WL. The mechanism of pain in gastric and in duodenal ulcer. II. The production of pis by means of chemical irritants. Arch Intern Med 1926;38:694-707.

10 Bonney GLW, Pickering GW. Observations on the mechanism of pain in ulcer of the stomach duodenum. Part II. The location of the pain nerve endings. Clin Sci 1946;6:91-111.

11 Mozsik G, Vizi F, Kutas J. A cellular-biochemical evaluation of gastric body mucosa and muscu解 layer in patients with different basal acid outputs. Scand $\mathcal{Y}$ Gastroenterol 1976;11:205-11.

12 Gerber JG, Fadul S, Payne NA, Nies AS. Adenosine: a modulator of gastric acid secretion in viæ I Pharmacol Exp Ther 1984;231:109-13.

13 Bruns RF. Adenosine receptor activation by adenine nucleotides requires conversion of the nucleotides to adenosine. Archives of Pharmacology 1980;315:5-13.

14 Belardinelli L, Shryock J, West GA, Clemo HF, DiMarco JP, Berne RM. Effects of adenosine and adenine nucleotides on the atrioventricular node of isolated guinea pig hearts. Circulations 1984;70:1083-91.

15 Bleehen T, Hobbiger F, Keele CA. Identification of algogenic substances in human erythrocy⿺ I Physiol 1976;262:131-49.

16 Drury AN, Szent-Gyorgyi A. The physiological activity of adenine compounds with espectin reference to their action upon the mammalian heart. $f$ Physiol 1929;68:213-37.

17 Puurunen J, Aittakumpu R, Tanskanen T. Vagally mediated stimulation of gastric acid secretio by intravenously administered adenosine derivatives in anaesthetised rats. Acta Pharmatol Toxicol (Copenh) 1986;58:265-71. 18 Kang JY, Yap I, Guan R, Tay HH. Acid perfusion of duodenal ulcer craters and ulcer paino్
controlled double blind study. Gut 1986;27:942-5. 19 Sylven C, Beermann B, Jonzon B, Brandt R. Angina pectoris-like pain provoked by intravenoits
adenosine in healthy volunteers. BrMed $\mathcal{F}$ 1986;293:227-30.

20 Watt AH, Singh H, Penny WJ. The effect of adenosine on coronary flow and left ventricumar function in man. Pflugers Arch 1986;407 (suppl 1):54.

21 Watt AH, Reid PG, Stephens MR, Routledge PA. Adenosine-induced respiratory stimulation depends on site of infusion. Evidence for an action on the carotid body? Br f Clin Pharmasepl 1986;22:238-9.

22 Klabunde RE. Dipyridamole inhibition of adenosine metabolism in human blood. Eu Pharmacol 1983;93:21-6.

(Accepted 13 October 1986)

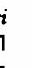

